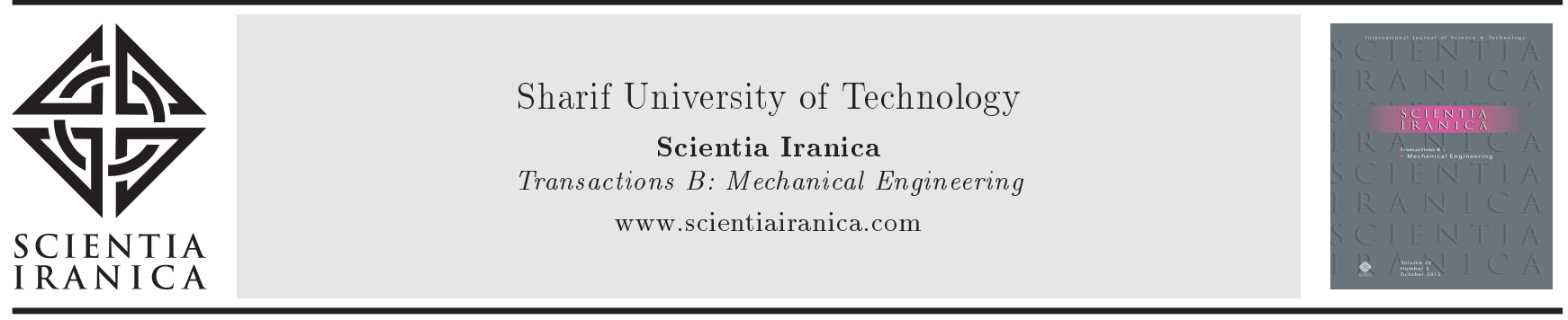

\title{
Utilization of charcoal in the iron-ore sintering process
}

\author{
J. Legemza*, R. Findorák and M. Fröhlichová \\ Department of Ferrous Metallurgy and Foundry, Faculty of Metallurgy, Technical University of Košice, Slovakia.
}

Received 4 April 2014; received in revised form 24 April 2015; accepted 17 August 2015

KEYWORDS
Biomass;
Coke breeze;
Charcoal;
Iron-ore sintering
process;
Thermodynamic
analysis;
Laboratory sinter-pot;
Sinter quality.

\section{Introduction}

Sintering is an agglomeration process that is used in the iron industry to prepare fine grained iron bearing materials for use in the blast furnace. Sinter composition usually depends on chemical composition of input materials, carbon content, oxidation potential of the gaseous phase, and temperatures in the sintering bed [1]. Agglomeration process is mainly the oxidation process, which is based on combustion of carbon with oxygen to form $\mathrm{CO}_{2(g)}$ and $\mathrm{CO}_{(g)}$. Reaction of complete combustion of carbon is the dominant chemical reaction in the agglomeration process and it brings the largest heat effect into the process.

Possible solutions for reduction of energy-emission load of the agglomeration process of fine iron bearing

\footnotetext{
*. Corresponding author. Tel.: +421055 602 3155

E-mail address: jaroslav.legemza@tuke.sk (J. Legemza)
}

\begin{abstract}
Charcoal is becoming an alternative source of energy to traditional fossil fuels as coal and coke. In theoretical studies, some types of biomass have been identified alternative sources of fuel to coke. The use of charcoal for sintering applications has charcoal can replace a portion of the coke breeze (approximately 20-30\%). The aim of this enamic study was to evaluate the possibilities of charcoal utilization in iron-ore sintering process. Thermodynamic analysis has shown that the main factors determining the composition and properties of sinter are chemical composition of input materials (ing ox fuels burning, and oxidation potential of the coke substitution by charcoal in the laboratory sintering process with respect to combustion coke substitution and energy requirement provided by time and the replacement of coke with charcoal may lead to increase in sinter productivity.
\end{abstract} (C) 2016 Sharif University of Technology. All rights reserved. 
- $\operatorname{Cobs}(<3 \mathrm{~mm})$;

- Bark from trees $(<3 \mathrm{~mm})$;

- Sawdust from pine wood $(<3 \mathrm{~mm})$, pressed sawdust $(<4 \mathrm{~mm}$, and $<2 \mathrm{~mm})$

- Olive pulp;

- Almond nut shells ( $<2 \mathrm{~mm})$;

- Hazelnut shells $(<2 \mathrm{~mm})$;

- Rape straw, rape seed;

- Charcoal $(<3 \mathrm{~mm}$, and $<8 \mathrm{~mm})$.

The results of the studies suggest that the size of plant and sawdust biomass particles should be smaller than those in case of coke where the threshold is less than $3 \mathrm{~mm}$. Charcoal should be used in fraction under $3 \mathrm{~mm}$; for sawdust the particles should be under $1 \mathrm{~mm}$ and for plants from 0.6 to $0.8 \mathrm{~mm}$.

Biomass is characterized by relatively high and frequently changing water content, which considerably affects energy properties of biomass fuel. Particular types of biomass (mainly of vegetation and wood origin) have significantly higher content of volatile combustibles than coke breeze. The analyses of individual types of biomass used for iron bearing agglomerate production over the world are given in Table 1 [2-4].

In various studies over the world, charcoal has been tested as a replacement for coke breeze in iron bearing materials sintering. Generalized knowledge is introduced about charcoal use from the results of these studies in the following text $[2,5,6]$ :

- It is possibly effective to replace about $20-30 \%$ of coke breeze by charcoal in agglomeration;
- Replacement of coke breeze by charcoal has been tested up to $100 \%$;

- Bulk density of tested agglomeration mixtures decreases with increasing charcoal ratio;

- Efficiency of combustion is higher than when using coke breeze alone;

- Maximum temperatures during agglomeration process are lower with charcoal than with coke breeze and also temperature profile is broad within individual levels of temperature reading;

- When using charcoal, overall time of sintering gets shorter and productivity increases;

- The use of charcoal over the world caused lower quality of produced iron bearing agglomerate, increasing the proportion of recycled agglomerate (under 5 $\mathrm{mm}$ ) by ISO test (fraction under $0.5 \mathrm{~mm}$ ).

Studies over the world prove that complete replacement of coke breeze by biomass in agglomeration is not possible. In general, the studies show that there is a potential for emission reduction and productivity enhancement by biomass use in agglomeration process. However, there is a need for further study on the effect of individual parameters of biomass on the qualitative parameters of the produced agglomerate (mainly on the oversize agglomerate yield and on its strength).

\section{Materials and methods}

For the experiments, iron-ore, iron concentrate, dolomite, limestone, coke breeze, and charcoal were used. Table 2 shows the chemical analysis of iron

Table 1. Analyses of the selected materials [2-4].

\begin{tabular}{lcccccc}
\hline Selected carbon materials & $\begin{array}{c}\text { Moisture } \\
{[\%]}\end{array}$ & $\begin{array}{c}\text { Ash } \\
{[\%]}\end{array}$ & $\begin{array}{c}\text { Volatiles } \\
{[\%]}\end{array}$ & $\begin{array}{c}\text { Fixed carbon } \\
{[\%]}\end{array}$ & $\begin{array}{c}\text { Sulfur } \\
{[\%]}\end{array}$ & $\begin{array}{c}\text { Calorific } \\
\text { value [MJ/kg] }\end{array}$ \\
\hline Coke breeze [2] & 5.5 & 12.1 & 1.5 & 84.4 & 0.60 & 28.00 \\
Coke breeze [3] & 0.1 & 13.3 & 1.8 & 84.9 & 0.51 & 28.75 \\
Coke breeze [4] & - & 19.5 & 5.8 & 74.6 & 0.50 & 26.84 \\
Sunflower husks [2] & 9.3 & 3.2 & 76.4 & 12.3 & 0.14 & 16.00 \\
Hazelnut shells [2] & 11 & 1.1 & 67.8 & 20.0 & 0.04 & 18.20 \\
Almond shells [2] & 9.3 & 0.5 & 81.4 & 8.8 & 0.03 & 16.70 \\
Rape straw [2] & 9.8 & 2.8 & 81.2 & 6.0 & 0.11 & - \\
Rape seed [2] & 8.1 & 4.5 & 83.2 & 3.6 & 0.60 & 17.37 \\
Bark [3] & 7.3 & 3.0 & 75.7 & 21.3 & 0.02 & 18.68 \\
Sawdust [3] & - & 0.3 & 85.4 & 14.3 & 0.01 & 17.53 \\
Corn [3] & - & 1.6 & 83.2 & 15.2 & 0.05 & 16.11 \\
Charred-straw [4] & - & 5.1 & 23.6 & 71.2 & 0.08 & 28.77 \\
Charcoal [2] & 4.6 & 4.5 & 32.7 & 58.2 & 0.02 & 33.10 \\
Charcoal [3] & 18.0 & 6.1 & 17.0 & 76.9 & 0.02 & 29.93 \\
Charcoal [4] & - & 5.1 & 7.5 & 87.3 & 0.04 & 30.77 \\
\hline
\end{tabular}


Table 2. Chemical analysis of iron bearing materials.

\begin{tabular}{ccc}
\hline Elements & $\begin{array}{c}\text { Concentrate } \\
{[\%]}\end{array}$ & $\begin{array}{c}\text { Iron-ore } \\
{[\%]}\end{array}$ \\
\hline $\mathrm{Fe}_{\text {total }}$ & 67.91 & 56.19 \\
$\mathrm{FeO}$ & 28.45 & 0.72 \\
$\mathrm{Fe}_{2} \mathrm{O}_{3}$ & 65.57 & 79.55 \\
$\mathrm{SiO}_{2}$ & 4.92 & 17.2 \\
$\mathrm{CaO}$ & 0.21 & 0.1 \\
$\mathrm{MgO}$ & 0.34 & 0.27 \\
$\mathrm{Al}_{2} \mathrm{O}_{3}$ & 0.18 & 0.59 \\
\hline
\end{tabular}

Table 3. Analyses of the selected carbon materials.

\begin{tabular}{lcc}
\hline \multicolumn{1}{c}{$\begin{array}{c}\text { Properties } \\
\text { of fuels }\end{array}$} & $\begin{array}{c}\text { Coke } \\
\text { breeze }[\%]\end{array}$ & $\begin{array}{c}\text { Charcoal } \\
{[\%]}\end{array}$ \\
\hline Total moisture $\left(\mathrm{W}^{a}\right)$ & 0.8 & 1.8 \\
Ash $\left(\mathrm{A}^{d}\right)$ & 14.5 & 2.3 \\
Volatile matter $\left(\mathrm{V}^{\text {daf }}\right)$ & 3.5 & 6.4 \\
Hydrogen $\left(\mathrm{H}^{\text {daf }}\right)$ & 0.79 & 1.39 \\
Carbon $\left(\mathrm{C}^{\text {daf }}\right)$ & 96.9 & 94.4 \\
Nitrogen $\left(\mathrm{N}^{\text {daf }}\right)$ & 0.84 & 0.44 \\
Calorific value $\left(\mathrm{Q}_{i}^{d}\right)$ & $28.16[\mathrm{MJ} / \mathrm{kg}]$ & $32.05[\mathrm{MJ} / \mathrm{kg}]$ \\
\hline
\end{tabular}

bearing materials used in this study. Both the charcoal and coke breeze used in this study were subjected to chemical analysis, typically used for coal characterization (Table 3).

Charcoal has approximately the same content of carbon and higher volatile matter content as those in coke breeze. Commercial charcoal has a high calorific value $(32.05 \mathrm{MJ} / \mathrm{kg})$ and coke breeze has the calorific value of $28.16 \mathrm{MJ} / \mathrm{kg}$. It can be observed from the chemical analyses that commercial charcoal has much lower ash content than coke breeze.

The available commercial charcoal is not directly suitable for agglomeration because of its oversized granularity. The biomass charcoal was reduced in size using a hammer mill and the size fraction $<3 \mathrm{~mm}$ was separated using a test sieve shaker. In Figure 1, the original and ground samples of charcoal are shown.

The methodology of preparation and the course of the experiment were in concordance with the technology of preparation and processing used under standard

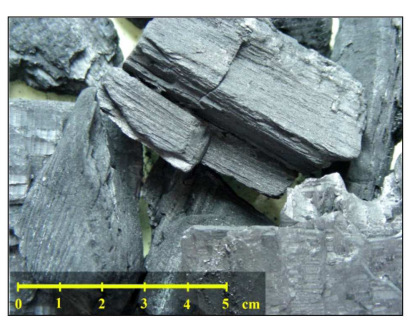

(a)

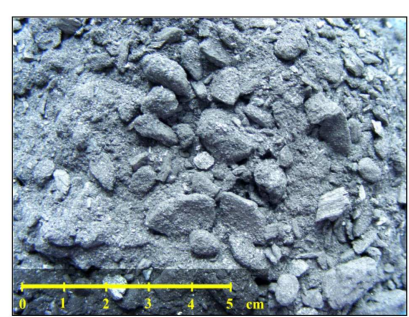

(b)
Figure 1. Charcoal sample: (a) Original; and (b) ground.

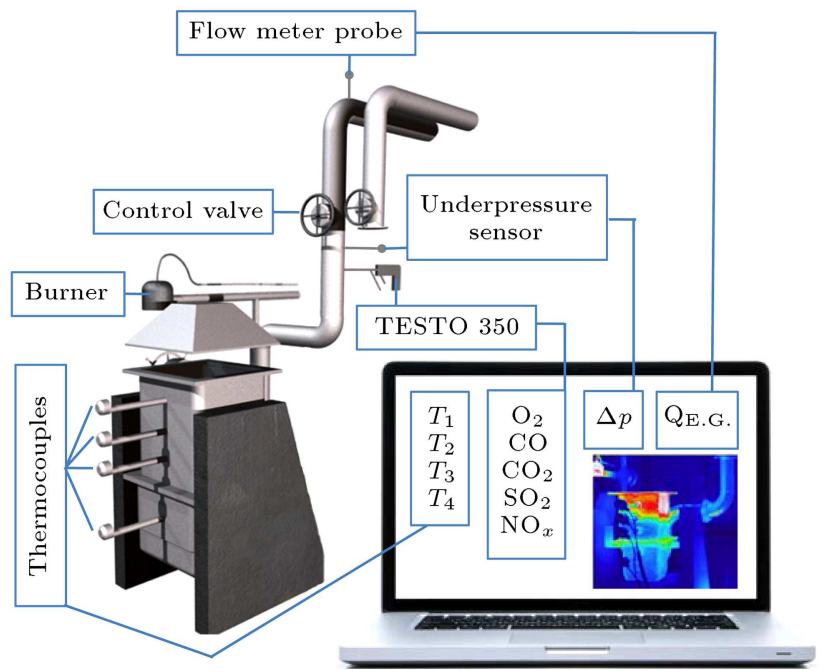

Figure 2. Schematic diagram of the Laboratory Sintering Pot (LSP).

operational conditions $[1,12,14,15]$. The process was carried out by wet-mixing a carefully blended mixture of homogenized materials with coke breeze and charcoal. The sinter batch was charged as micropellets into the Laboratory Sintering Pot (LSP), as shown in Figure 2. After ignition, the sintering process has been carried out while maintaining the constant under pressure of $5 \mathrm{kPa}$. Airflow measurements were made in the offgas passage where the hot exhaust gas had been cooled. Thermocouples were installed at depths of $100 \mathrm{~mm}, 200 \mathrm{~mm}$, and $300 \mathrm{~mm}$ through the sinter bed. The concentrations of carbon dioxide, carbon monoxide, sulphur dioxide, and nitric oxide were measured using a Testo 350 portable emission analyzer. Sintering process was continuously monitored and recorded. Laboratory sintering pot sufficiently simulated the conditions of the sinter belt in relation to the production of $\mathrm{CO}, \mathrm{CO}_{2}, \mathrm{NO}_{x}, \mathrm{SO}_{x}$, and solid polluting substances in the sintering process.

\section{Results and discussion}

The aim of this study was to evaluate, from the thermodynamic point of view, the possibilities of charcoal utilization in iron-ore sintering process. The course and a thermal effect of individual reactions that take place during combustion of carbonaceous fuels (coke breeze or charcoal) in the agglomeration process were modeled using thermodynamic program HSC Chemistry 5.11. In Figure 3, Gibbs equilibrium diagrams are modeled for agglomeration charge sintering systems in the presence of coke breeze and charcoal. In the calculations, the following parameters of sintering charge were considered: $\left(\mathrm{Fe}_{\text {total }}=44 \%\right.$, basicity $=1.6$, moisture $=7 \%$, content of fuel $=3.8 \%$ ). Sintering was modeled for $100 \mathrm{~kg}$ of batch in the presence of $45 \mathrm{~m}^{3}$ of air throughput (standard sintering conditions) [9]. 

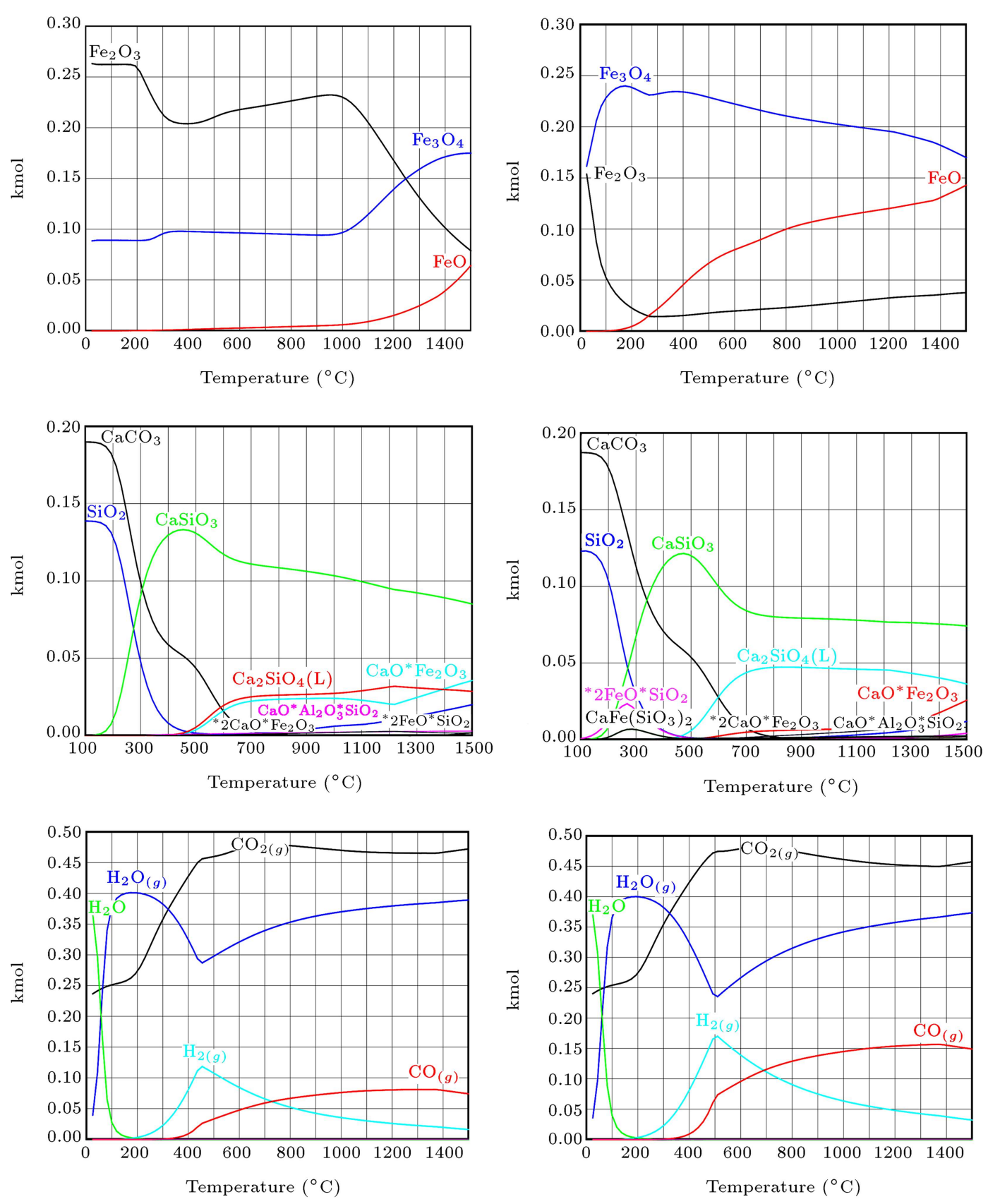

(a) Coke breeze

(b) Charcoal

Figure 3. Equilibrium diagrams for sintering the mixture with (a) coke breeze, and (b) charcoal [9].

When commercial charcoal is used for sintering, there is higher content of $\mathrm{CO}_{(g)}$ and $\mathrm{H}_{2(g)}$ present in the gaseous phase, which is also reflected by a higher content of $\mathrm{Fe}_{3} \mathrm{O}_{4}$ and $\mathrm{FeO}$ in the resulting agglomerate. On the other hand, when producing agglomerate using charcoal, it is possible to expect lower content of calcium ferrites, which can result in a product with lower compression strength. Given the significantly higher proportion of ash in the coke breeze than that in charcoal, there can be expected a higher proportion of silicates in the resulting agglomerate structure (using coke breeze), as shown in Figure 3(a).
Laboratory experiments were carried out with coke-biomass mixtures in which $8 \%, 20 \%, 50 \%$, and $86 \%$ of the energy requirement was provided by charcoal. In all the sintering experiments, the total energy content of the fuel was the same as that for $3.8 \mathrm{wt} . \%$ of coke [14].

In Figure 4, the sintering of agglomeration mixture in laboratory sintering pot is shown. During the sintering, the laboratory sintering pot was monitored by thermovision camera and movement of the combustion zone in the direction of airflow was recorded. The movement of the combustion zone from upper to 


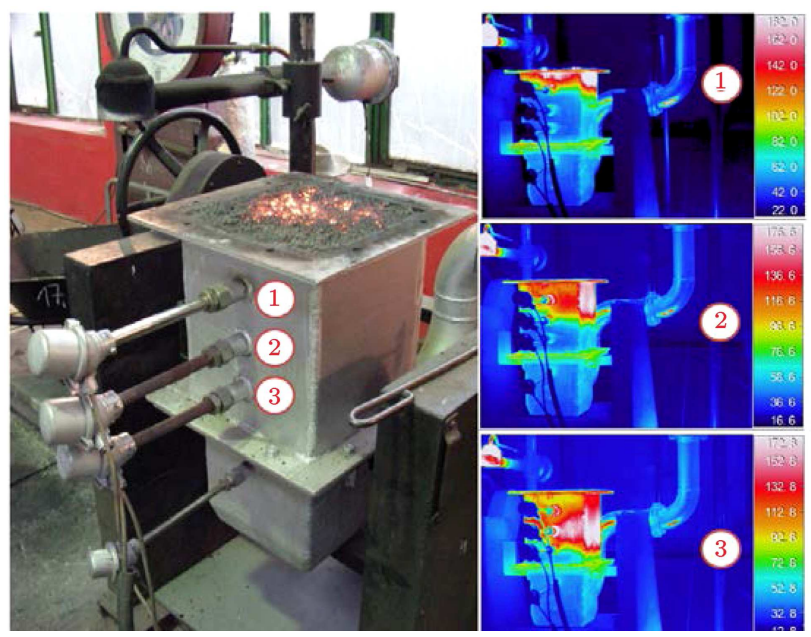

Figure 4. Depiction of laboratory sintering pot and fuel combustion zone in the sintering bed: zone 1: 2 minutes; zone 2: 13 minutes; and zone 3: 20 minutes.

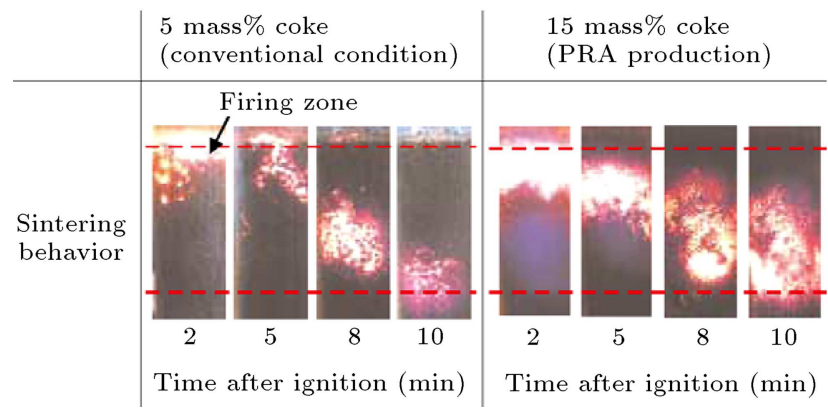

Figure 5. Influence of coke breeze mixing ratio on the combustion zone [10].

lower during the sintering process was observed for approximately 20 minutes (20\% replacement of the coke with charcoal).

In comparison with the research in Japan [10], the movement of the combustion zone from upper to lower was observed using a silica glass tube in the pot test (only with coke), as shown in Figure 5.

The temperatures (measured by thermocouples), attained at various bed depths during combustion of coke, and coke-charcoal mixtures, with 0\%,20\%,50\%, and $86 \%$ replacement of the coke, in the combustion zone reach $900-1380^{\circ} \mathrm{C}$. Figure 6 shows the temperature profile usually observed during iron-ore sintering experiments at LSP. All temperatures were comparable to temperatures observed in an industrial sintering bed. The maximum off-gas temperatures measured in the sinter pot windbox were in the range of 530$630^{\circ} \mathrm{C}$. As the proportion of charcoal used in the sintering pot increased, the bed temperatures were reduced.

In comparison with the research in Australia and UK [6], it may be seen from Figure 7 that the peak temperatures, attained at $100 \mathrm{~mm}$ of depth (during iron-ore sintering experiments), are dependent on the proportion of substituted coke. The highest bed temperature (i.e., $1320^{\circ} \mathrm{C}$ ) was obtained with the test blend consisting of $20 \%$ substitution of coke breeze energy with charcoal followed by $100 \%$ coke breeze.

In Figure 8, the influence of charcoal ratio on maximum temperatures in sintering bed is shown. With increasing proportion of charcoal in the total quantity of the fuel, maximum temperatures were attained in the individual levels of sintering charge decline. This effect gets more significant in direction of the airflow and is most pronounced at the bottom of the laboratory sintering pot.

Concentrations of $\mathrm{CO}, \mathrm{CO}_{2}$, and $\mathrm{O}_{2}$ in the flue gas and combustion efficiency during sintering mixture for various contents of charcoal in sintering bed were measured and analyzed. Figure 9 shows the concentrations of $\mathrm{CO}, \mathrm{CO}_{2}$, and $\mathrm{O}_{2}$ and combustion efficiency during sintering of mixture without charcoal. Figures 10 and 11 show the concentrations of $\mathrm{CO}, \mathrm{CO}_{2}$, and $\mathrm{O}_{2}$ and combustion efficiency for individual cases (20 and $50 \%$ replacement of coke with charcoal) [11].

As may be seen, the carbon monoxide and carbon dioxide concentration profile exhibited a strong peak when $50 \%$ of coke breeze was replaced with charcoal (Figure 11), which perhaps indicates the accumulation of condensible and combustible volatile matter from the charcoal.

The content of $\mathrm{Fe}_{\text {total }}$ in the final agglomerates was approximately $52 \%$ (content of $\mathrm{FeO}$ was at intervals of $5-9 \%$ ). The use of charcoal fuel results in a decrease in the sintering time and the replacement of coke with charcoal may lead to an increase in sinter productivity. The level of produced return fines is considered the most direct indicator of sinter quality. It was observed that coke replacement with charcoal in blends has no significant influence on the strength of the sintered product. On the other hand, coke substitution with charcoal has negative effect on abrasion (Figure 12) [12] and reducibility agglomerate [13].

Charcoal is similar to coke in terms of its general chemistry, but with very low ash levels, and therefore would not normally present additional chemical risks in replacing the conventional fuels. On the other side, charcoal production has been singled out as a major cause of forest degradation and deforestation in many countries. There are some types of products and byproducts from charcoal production operations: charcoal, carbon monoxide ( $\mathrm{CO})$, carbon dioxide $\left(\mathrm{CO}_{2}\right)$, methane $\left(\mathrm{CH}_{4}\right)$, tars, and water. In addition to the issue of deforestation, greenhouse gas emissions are also released, ranging between $7-9 \mathrm{~kg}$ of $\mathrm{CO}_{2}$ equivalent per kilogram of produced charcoal. Methane is the most potent greenhouse gas. Many other products of incomplete combustion are also emitted from pyrolytic process, most of which are also 


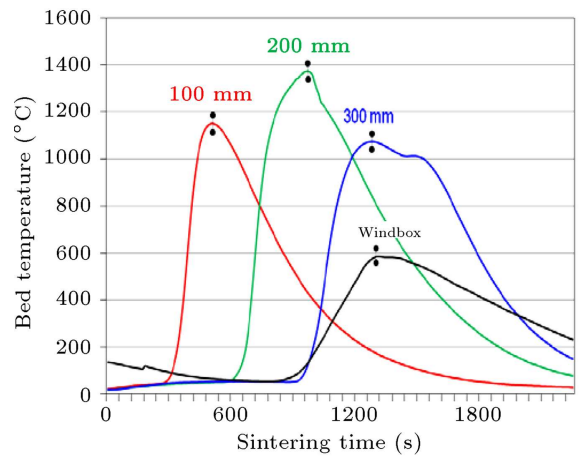

(a)

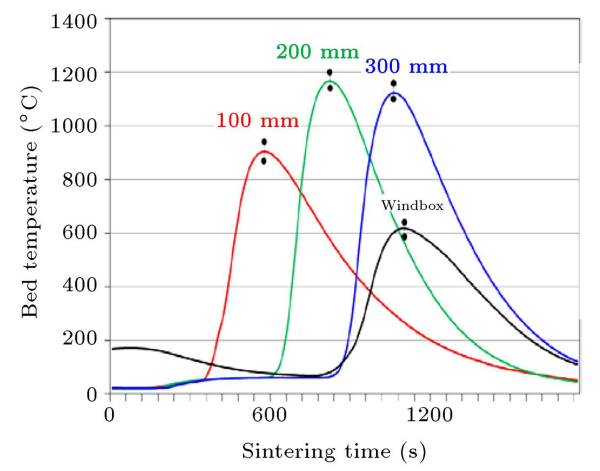

(c)

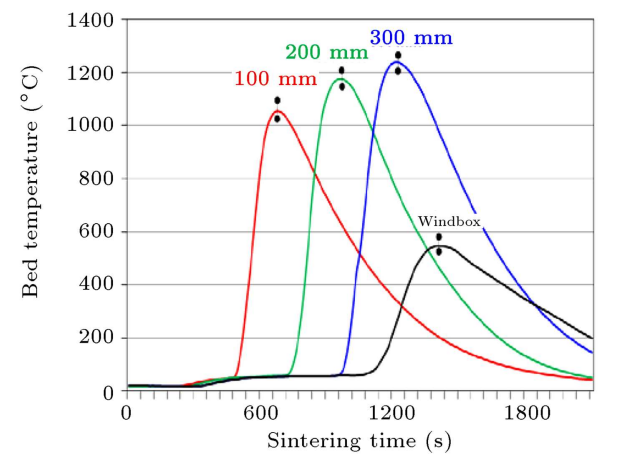

(b)

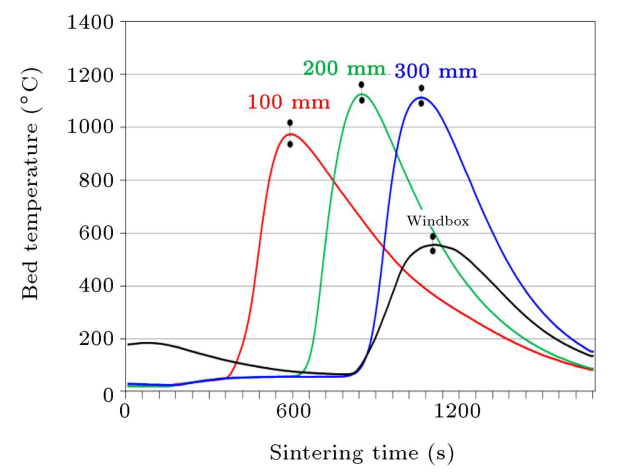

(d)

Figure 6. Bed temperatures profile with (a) $0 \%$ coke substitution, (b) $20 \%$ coke substitution, (c) $50 \%$ coke substitution, and (d) $86 \%$ coke substitution.

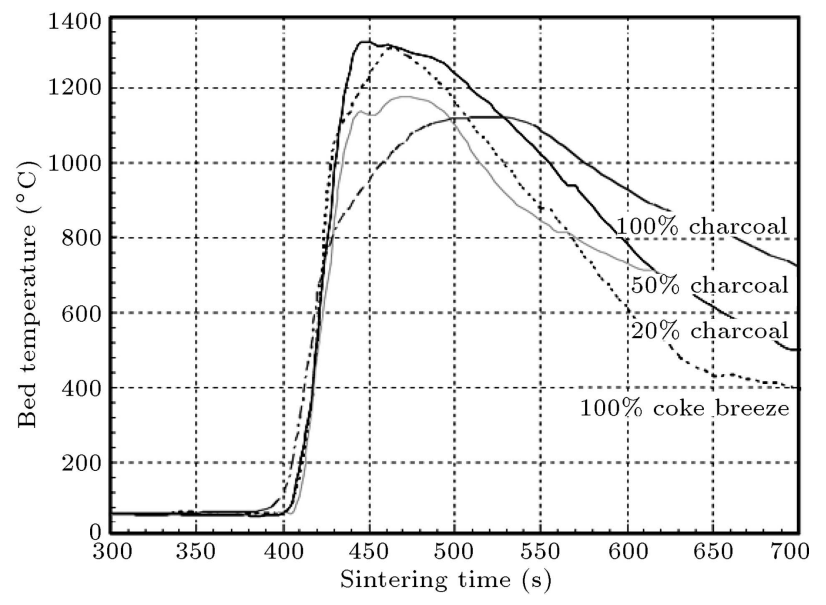

Figure 7. Sinter bed thermal profiles at $100 \mathrm{~mm}$ of bed depth during sintering of iron-ore with coke and charcoal [6].

known to contribute to regional and global atmospheric pollution that leads to negative environmental impacts. These negative environmental effects can be minimized through planned production of charcoal and utilization of more efficient technologies which will require almost half of the quantities of wood for charcoal production and at the same time release lower quantities of pollutants into the environment. Improved kiln technologies can increase carbonization efficiency while additionally reducing greenhouse gas emissions. The

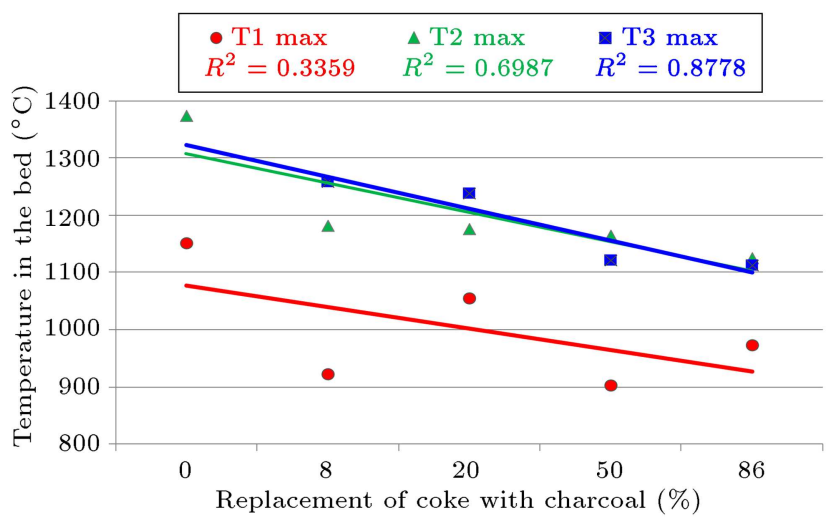

Figure 8. Influence of the replacement of coke with charcoal on temperatures in bed.

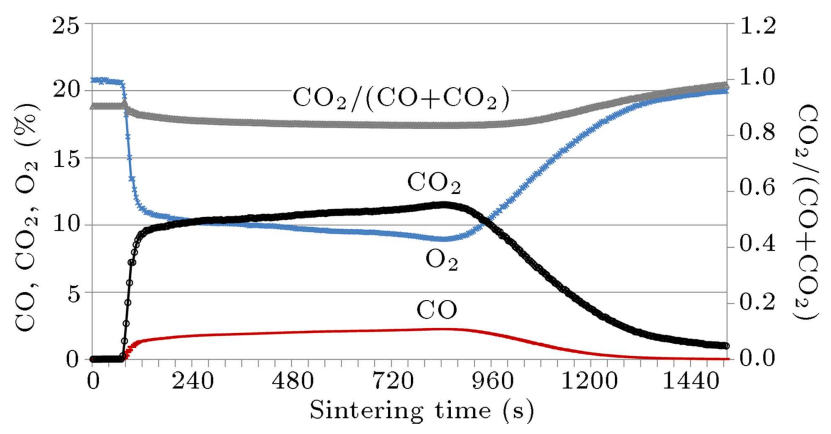

Figure 9. Concentrations of $\mathrm{CO}, \mathrm{CO}_{2}$, and $\mathrm{O}_{2}$ in the flue gas and combustion efficiency during sintering of mixture without charcoal [11]. 


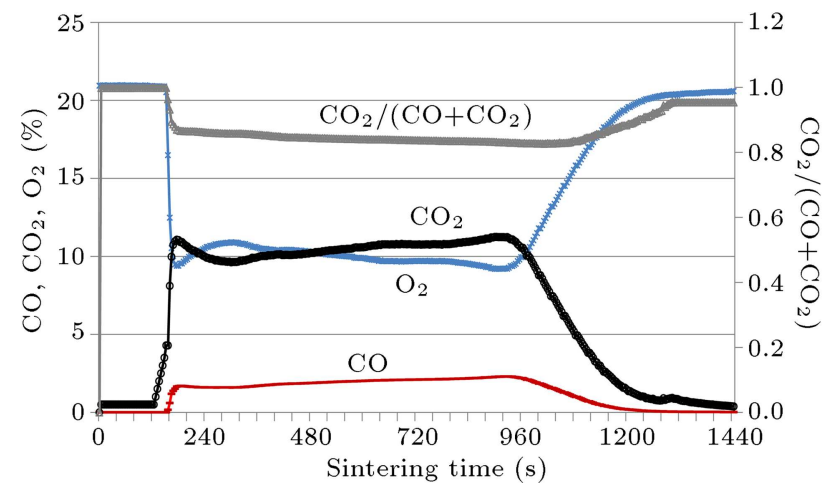

Figure 10. Concentrations of $\mathrm{CO}, \mathrm{CO}_{2}$, and $\mathrm{O}_{2}$ in the flue gas and combustion efficiency during sintering of mixture with $20 \%$ replacement of coke with charcoal [11].

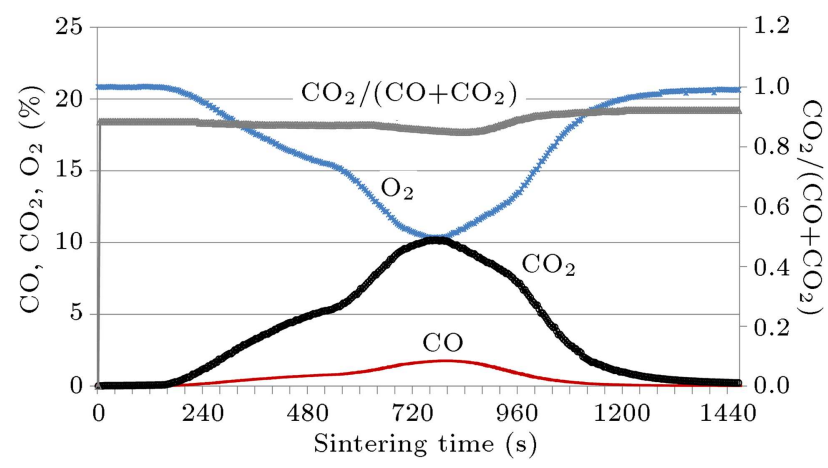

Figure 11. Concentrations of $\mathrm{CO}, \mathrm{CO}_{2}$, and $\mathrm{O}_{2}$ in the flue gas and combustion efficiency during sintering of mixture with $50 \%$ replacement of coke with charcoal [11].

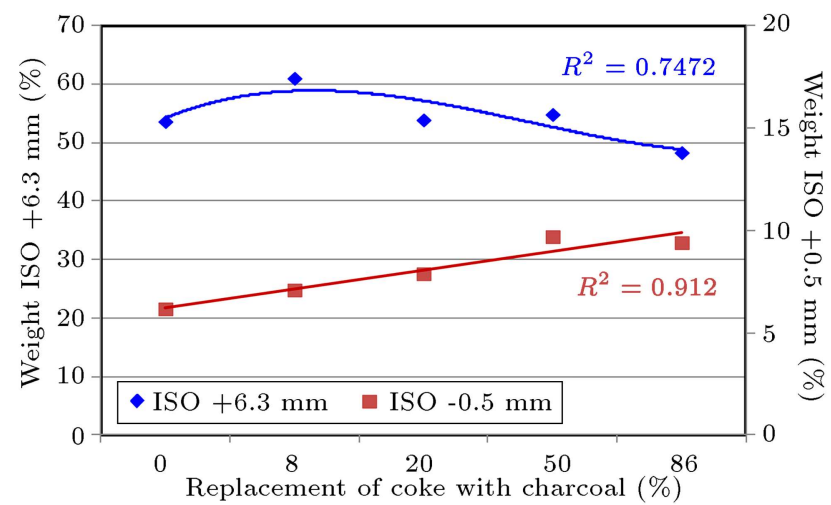

Figure 12. The effect of coke replacement by charcoal addition on agglomerate quality.

charcoal briquetting process is also a potential source of emissions. The crushing, screening, and handling of the dry raw charcoal may produce PM and PM10 emissions. Briquette pressing and drying may be a source of VOC emissions. However, the replacement of coke with an equivalent amount of charcoal would mean that a part of the $\mathrm{CO}_{2}$ emitted from sinter plants would be from a renewable source and could be used to offset $\mathrm{CO}_{2}$ from non-renewable fossil fuels. But, despite the negative effects that its production causes, charcoal can nevertheless be seen as a product offered gracefully by nature and it constitutes a future energy.

\section{Conclusion}

The aim of this study was to determine the possibility of using charcoal in the agglomeration process based on a comparison between the composition of coke breeze and charcoal. It can be concluded:

1. Studies over the world prove that complete replacement of the coke breeze by biomass in agglomeration is not possible. These experiments indicate that charcoal can replace a portion of the coke breeze (approximately 20-30\%);

2. Subsequent studies on model systems using both types of carbonaceous fuels showed that from thermodynamic point of view, the use of charcoal reduced the $\mathrm{CO}_{2(g)} / \mathrm{CO}_{(g)}$ ratio in the exhaust gases and there was also higher content of $\mathrm{H}_{2(g)}$, which was also reflected by a higher content of $\mathrm{Fe}_{3} \mathrm{O}_{4}$ and $\mathrm{FeO}$ in the resulting agglomerate;

3. In the laboratory experiments, it was found that the movement of the combustion zone from upper to lower during the sintering process (monitored by thermovision camera) was observed approximately 20 minutes (with coke-charcoal mixtures);

4. The temperatures attained at various bed depths during combustion of coke-charcoal mixtures, with $20 \%, 50 \%$, and $86 \%$ replacement of the coke, in the combustion zone reach $900-1239^{\circ} \mathrm{C}$. The combustion of coke with specified substitution by charcoal resulted in reduced bed temperatures with the reduction in temperature increase as the amount of charcoal increased;

5. The use of charcoal fuel resulted in a decrease in the sintering time [12];

6. This decrease in sintering time suggests that perhaps the replacement of coke with charcoal may lead to an increase in sinter productivity [12];

7. Addition of charcoal instead of coke has a negative effect on sinter strength, where the total loss is about $5 \%$ in case of maximum coke replacement. Abrasion of agglomerate increased with increasing charcoal proportion in the mixture;

8. Average concentrations of $\mathrm{CO}$ and $\mathrm{CO}_{2}$ decreased with addition of charcoal by approximately 30 $40 \%$.

\section{Acknowledgments}

This work was supported by Slovak Research and Development Agency (APVV), Slovak Republic, No. APVV-0405-11. 


\section{References}

1. Legemza, J., Fröhlichová, M., Findorák, R. and Bakaj, F. "The process of simulating the agglomerate laboratory production under laboratory conditions", Acta Metallurgica Slovaca, 1, pp. 70-75 (2010).

2. Zandi, M., Martinez-Pacheco, M. and Fray, T. "Biomass for iron-ore sintering", Minerals Engineering, 22(14), pp. 1139-1145 (2010).

3. Thomas, S., Mcknight, J.S., Serrano, E.J., Mašlejová, A., Želinský, R., Tomáš, J. and Vlašič, P. "Laboratory evaluation of biomass usage for coke and sinter production", Paper Presented at the Conference Alternative Fuels in Iron- and Steelmaking, Session 9, Düsseldorf (2011).

4. Gan, M., Fan, X., CHen, X., Ji, Z., Lv, W., Wang, Y., Yu, Z. and Jiang, T. "Reduction of pollutant emission in iron-ore sintering process by applying biomass fuels", ISIJ International, 52(9), pp. 15741578 (2012).

5. Ooi, T.Ch., Aries, E., Ewan, B.C.R., Thompson, D., Anderson, D.R., Fisher, R., Fray, T. and Tognarelli, D. "The study of sunflower seed husks as a fuel in the iron-ore sintering process", Minerals Engineering, 21(2), pp. 167-177 (2008).

6. Ooi, T. Ch., Thompson, D., Anderson, D.R., Fisher, R., Fray, T. and Zandi, M. "The effect of charcoal combustion on iron-ore sintering performance and emission of persistent organic pollutants", Combustion and Flame, 158, pp. 979-987 (2011).

7. Llorente, M.J.F. and Garcia, J.E.C. "Comparing methods for predicting the sintering of biomass ash in combustion", Fuel, 84, pp. 1893-1900 (2005).

8. Zandi, M., Martinez-Pacheco, M. and Fray, T. "Biomass for iron-ore sintering", Minerals Engineering, 23, pp. 1139-1145 (2010).

9. Legemza, J., Fröhlichová, M. and Findorák, R. "Thermodynamic study of utilization of charcoal in the iron-ore sintering process", Paper Presented at the SGEM 2013, 13th International Multidisciplinary Scientific Geoconference, 2, Bulgaria, Albena, pp. 649-655 (2013).

10. Machida, S., Sato, H. and Takeda, K., JFE Technical Report, 1(13), pp. 7-13 (2009).

11. Findorák, R., Fröhlichová, M. and Legemza, J. "The effect of charcoal addition on iron-ore sintering emis- sions", Paper Presented at the SGEM 2013, 13th International Multidisciplinary Scientific Geoconference, 2, Bulgaria, Albena, pp. 629 - 635 (2013).

12. Findorák, R., Fröhlichová, M. and Legemza, J. "The effect of charcoal addition on iron-ore sintering performance", Paper Presented at the SGEM 2013, 13th International Multidisciplinary Scientific Geoconference, 2, Bulgaria, Albena, pp. 637-642 (2013).

13. Pustějovská, P., Jursová, S., Brožová, S. "Determination of kinetic constants from tests of reducibility and their application for modelling in metallurgy", Journal of the Chemical Society of Pakistan, 35(3), pp. 565-569 (2013).

14. Findorák, R., Fröhlichová, M. and Legemza, J. "The study of saw-dust addition on iron-ore sintering performance", Acta Metallurgica Slovaca - Conference, 4, pp. 23-30 (2014).

15. Legemza, J., Fröhlichová, M., Findorák, R. and Bakaj, F. "The simulating of production the agglomerate in laboratory sintering pan", Acta Metallurgica Slovaca, 17 (4), pp. 245-252 (2011).

\section{Biographies}

Jaroslav Legemza, PhD, is currently Associate Professor in the Department of Ferrous Metallurgy and Foundry, Faculty of Metallurgy, Technical University of Košice, Slovak republic. His research interests include agglomeration process, blast furnace process, production of ferroalloys, and thermodynamic analysis.

Róbert Findorák, PhD, is currently Assistant Professor in the Department of Ferrous Metallurgy and Foundry, Faculty of Metallurgy, Technical University of Košice, Slovak republic. His research interests include agglomeration and pelletizing process, blast furnace process, and analysis of iron-ore materials.

Mária Fröhlichová, $\mathrm{PhD}$, is currently chief and Professor in the Department of Ferrous Metallurgy and Foundry, Faculty of Metallurgy, Technical University of Košice, Slovak republic. Her research interests include agglomeration and pelletizing process, blast furnace process, analysis of iron - ore materials, and refractory materials. 